\title{
Semantic Translation as Panacea to Misinformation in Literary Translation
}

\author{
Emeka C. Ifesieh \\ Delta State University, Abraka, Delta State, Nigeria
}

\begin{abstract}
Translatorial action is a Janus-headed enterprise, whose main objective is to transfer source language (SL) message(s) into a target language (TL). But it is noticeable from a preponderance of previous studies that in pursuance of either the dynamic or the optimum communicative equivalence, the translator often assumes a total authority of the original author. Subsequently, he/she recreates the SL message(s) in such a way that the TL message(s) leaves little or no trace to the SL text ingenuities. This is problematic, because the end-product of the translatorial action often fails to initiate the target audience into the peculiarities of the SL text. The TL audience is rather misinformed. Semantic approach to translation is explained as bearing on the semantic theory. The theory explains meaning in terms of naming relations that exist between the word and what it stands for in the real world. However, the existence of opaque contexts and words like prepositions, which do not refer to any tangible thing (known as their extensions) in the real world redirects the essence of the theory to concepts. Thus, within the broad theory of semantics, the conceptual theory is formulated to address the problems of opaque contexts and extensionalism by relating signs to concepts, that is, a capsule of thought that represents distinct experiences. Subsequently, the sense of a word is likened to concepts upon which real world experiences are pegged. Subsequently, a concept bears a sense(s) - the word's nucleus, which signifies or denotes, but does not connote; yet connotations rely on the sense to operate. Sequel to that, the semantic approach is used copiously to exemplify how the pursuance of sense relations in translatorial actions works for the recapturing of the situational context of the SL text production and ingenuities at the TL end as opposed to the communicatively translated texts. However, in the cases of use variations between the two languages in contact, the approach often fails to convey the message adequately and thereby necessitates the use of the communicative approach to translation.
\end{abstract}

Keywords: social context of SL text, thought process, semantic approach, Janus-headed enterprise, use variations

\section{Introduction}

Generally, two broad categories of translation definitions exist: the formal and the functional or socioculturally oriented definitions of translation. The socioculturally oriented definitions of translation suggest that translation is a specific form of human action and not necessarily a process of transcoding; that besides the client and the target readers, the major determinant of a translatorial action process is the function which the text

Emeka C. Ifesieh, senior lecturer, Ph.D., Department of Languages and Linguistics, Delta State University, Abraka, Delta State, Nigeria. 
is expected to perform in the culture of the target readers (Schäffner, 1998b, p. 235). Eco and Nergaard (1998), Lambert (1998), Reis (2004), and Vermeer (1998) share this view. In the view of these translation exponents, translation in primarily a process of intercultural communication, whose end product is a text capable of functioning appropriately in a specific situation and context of use. This is in agreement with the theory of translatorial action. In this conception, neither source and target text comparison nor linguistics has any significant role to play. Translation is situated within the wider context of cooperative interaction between experts and clients. In furtherance of this view, the translator is seen as an expert communicator at the nerve centre of a long chain of communication from the original initiator to the ultimate receiver of the message(s). The notion of function is important in dual dimensions: it compels the translator to embed the product of translatorial action into a complex situation of human needs. Again, it compels the translator to embed the translatorial action in the social order, that is in a hegemony organized by division of labour (Schäffner, 1998a, p. 3). Although the functional approach to translation brings in illuminations as regards independent challenges of target text production by shifting focus from the source text production conditions to that of target text, it erases identity indicators of the source cultural imagery and structures of expressions. It also distorts and misrepresents source cultural beliefs and ethos and imposes conformity conditions of the target socioculture upon the text. Furthermore, it silences the original authorial voice through the obliteration of his/her style, which is then supplanted with the translator's. Consequently, the translator achieves personal visibility at the expense of the social conditions of the original text production, local colours, imagery, style, structures, and forms of the source text. Subsequently, functional definition of translation is not readily adopted here as a suitable definition in approaching literary translatorial action. Sequel to that, a few formal definitions of translation are hereby examined.

\section{Defining Translation Linguistically}

Ajunwa (1991) defines translation as "a complex operation involving a systematic selection of linguistic items in the target language whose functions must be very close to those of the source language items" (p. 13). Ajunwa suggests that translation is intricate and meant for experts whose cognitive knowledge of the two languages in contact is sound. Also, of great essence is the sociocultural (functional) competence in handling the source text vis-à-vis the target text. This presupposes that the translator ought to be well groomed in both the source and the target linguistic and sociocultural environments.

Catford (1965) defines translation formally from a linguistic view point as "an operation performed on languages: a process of substituting a text in one language (SL) for a text in another (TL)" (pp. 1, 20). Here, emphasis is on the text; it is not actually the words that are the translatable units, but the texts, that is, the original words and sentences (structures) of the author. Lexical items in the SL text are replaced with their formal equivalents in the TL text. This definition rejects the communicative implication of translation in pursuit of sense relations in the SL with a view to replacing them with their formal equivalents at the TL end. Catford sees translation more or less as a scientific exercise. Therefore, Nida's (1959) dynamic equivalence (p. 19) and Koller's (1983) optimum communicative equivalence (p. 111) are excluded here as they fall outside the ambit of semantics, which is the scientific study of meaning (cf. Kempson, 1979, pp. 1-9; Malmkjaer, 2002, p. 455; Palmer, 2002, p. 5).

Bassnett (1996) defines translation as: 
The rendering of a SL text into the TL so as to ensure that (i) the surface meaning of the two texts will be approximately similar (ii) that the structures of the SL will be preserved as closely as possible, but not so closely that the TL structures will be seriously distorted. (p. 2)

Summarily, Ajunwa, Catford, and Bassnett's definitions have the following areas of convergence: they suggest universality of human language, though parameters may differ. Sequel to that, what can be said in the SL can equally be said in the TL (cf. Pedro, 1999, pp. 446-559). With the summings-up above, Ajunwa, Bassnett, and Catford's definitions are adopted as a part of the touchstone in handling the thesis of this write up. This is because the three authors view translation as a linguistic exercise whose main objective is to recapture the forms, style, local colours, textual functions, and sociocultural conditions of the SL text in the TL text. For example: "I saw men dancing with political erection. Sweat and sexual potency filled the air. Dancing women generated heat waves with the gyrations of their bottoms" (Okri, 1996, p. 154).

The social context of the above text is charged with tension, uncontrolled indulgence, illicit behaviour, shameless show of desire, and unbounded sexual ferocity. The focus here is on language in use, which is language that is functional. The thrust of Ajunwa, Catford, and Bassnett's view on translation for example, is that the social context manifested in the forms of the SL text above should be recaptured in a choice TL text through the application of semantically appropriate TL forms (cf. Ifesieh, 2010, p. 110).

\section{Theoretical Issues in Semantic Approach to Translation}

Semantic approach to translation originates from the semantic theory. In the theory, meaning is explicated in terms of naming relations which exist between words and what they stand for in the real world. At the foundational stage, the theory is extensionalism, whose main suggestion is that a relationship exists between an object and its referent. But the theory fails to account properly for how certain words refer to their so called extensions in the real world. For example, prepositions like to, for, with, in, into, from, about, around, on, below, and beside do not refer to anything concrete in the real world, yet they have meanings. Besides, certain lexical items have opaque contexts, e.g., believe, want, hope, and aspire which refer to no object in the real world, yet they have meanings. In a bid to solve the problem of opacity of lexical items and the failure of extensionalism to explain the relationship between certain words like prepositions and their referents, attempt is made to use the image theory to account for the meaning of words. The image theory attempts explanation of word meaning in terms of the images in the speaker's or listener's brain. But again, this approach creates the problem of knowing which form the images take: images are subject to speaker-hearer variations. Furthermore, how can the image theory account for words that do not evoke any image in the mind for example, because, and, therefore, but, and $o r$ ? Therefore, the conceptual theory of meaning takes care of the failures of extensionalism and the image theory of meaning. The theory addresses the problem of word meaning by relating signs to concepts, in other words, a capsule of thought that represents distinct experiences.

\section{Sense in Translation and the Conceptual Theory of Meaning}

According to Malmkjaer (2002), sense can be defined as:

The identifying sound or sign by means of which an object is picked out - it is a kind of verbal pointing; and understanding meaning amounts to knowing that this particular object is at this particular time being picked out by this particular sense. (p. 397) 
This definition is based on extensionalism which developed via the image theory into the conceptual theory of meaning. The core assumptions of the conceptual theory of meaning are that human mind is comparable to a blank slate at birth, but that since human beings share the same kind of sense organs and therefore experience the world in more or less the same way, they come in time to have more or less the same basic idea about it; that the very simplest concepts are natural or innate property of the human mind activated by experience not wholly and solely derived from it (cf. Clark \& Clark, 1977, p. 298; Harris, 1991, p. 323; Hampsher-Monk, 1992, p. 6; Goddard, 1998, p. 8). The conceptual theory is criticized on the ground that it is not susceptible to empirical verifications. However, an assertion can be made that the shortcoming can be covered when the domain of discourse in which such words that lack specific reference occur is investigated. For example, Seuren (1985) says: "The addresses, or discourse denotations are mapping targets for definite terms in sentences and at the same time, if the discourse is about real things, they stand in some defined relationship with the things the discourse is about" (p. 30).

Seuren argues in accordance with Structuralist School that utterances stand in certain relationship with the rest of the other words in the same utterance. This assertion buttresses the view that language is a system of interdependent terms in which the value of each term results solely from the simultaneous presence of others. Thus, concepts are developed on account of experiences got from the real world (cf. Ifesieh, 2010, p. 110).

\section{Word Functions in Sentential Structures}

Also, Ifesieh (2010) describes word functions in this order: Words are not the immediate constituents of sentences, yet they play an important role as the ultimate building blocks of the linguistic structure. Words belong to different syntactic categories, such as nouns, pronouns, verbs, prepositions, adjectives, adverbs, and conjunctions, and the syntactic category to which a word belongs determines its distribution. Lexical items do not occur indiscriminately in sentences, but occur according to certain rules, for example, the base rules which are made up of the lexical insertion, subcategorization, and the phrase structure rules. Under the subcategorization rules, there are the context free and context sensitive rules (Ndimele, 1999, p. 168). The emphasis is particularly on the context sensitive rule, which comprises the selectional restriction rules and the strict subcategorization rules, because the rule delimits the use of lexical items to the tacit knowledge of the language speaker. Selectional restriction rule is a condition which specifies the constraint on the possible combinations of lexical items within a given grammatical context. That means, it stipulates the conditions under which a lexical item must occur in the deep structure. The constraints, which are imposed on a particular lexical item in terms of the environment in which it must occur in the deep structure are stated with reference to the relevant natural semantic features of another lexical item in an adjacent syntactic environment (cf. Crystal, 2008). Selectional restriction rule specifies the semantic properties of lexical items in terms of qualities (components) such as "animacy", "humanness", and "concreteness". For example, "the famished road is eating the inhabitants of the land" (cf. Okri, 1996). The sentence is unacceptable because of the natural semantic property of the word "road". The above sentence is odd due to the fact that the verb "eat" is specified as (+ ANIMATE) and therefore cannot take a non-animate subject. The same oddity extends to the adjective, "famished" which qualifies the "road" in the sentence. In pragmatics, however, where messages conveyed do not bear any necessary relation to the linguistic content of the sentence used, the sample sentence above is acceptable provided that the cooperative principle is fulfilled (Kempson, 1979, 
p. 69). An assumption can therefore be made - that the effects of selection are tacitly connected to the sense of the verb. Therefore, selectional restriction rule is a semantic requirement. It suffices to say here that strict subcategorization is a syntactic requirement imposed on constituents of the sentence in terms of where they must occur (Ruwet, 1973, pp. 84-89; Radford, 1989, pp. 361-365; Haegeman, 1993, pp. 32-40; Brown \& Miller, 1992, pp. 147; Ndimele, 2004, p. 54).

\section{The Word's Nucleus as the Sense or the Invariant Core}

Ifesieh (2010) further argues that, it is known that every word has a conceptual nucleus within the semantic categories (p. 112). The nucleus constitutes the invariant core. Wierzbicka (1996) says: "To find the truth about the meaning of a word means to find the invariant concept which is part of the native speakers' tacit knowledge about their language and which guides them in their use of that word" (p. 264).

The idea of invariant core presupposes that every linguistic lexical item has an encoded concept. This is a scientific hypothesis which can be subjected to an empirical test. The argument that the conceptual theory of meaning is not susceptible to empirical verification is therefore contestable. While the concept is not accessible to direct observation, it is manifested in the use of a word. Accordingly, a definition can be tested against the range of use of a word which may be broad, but it has boundaries which are determined by the different components of the concept. The components of the concept determine which aspects of the use of a word/s is/are variable and which are invariable. It is one of the purposes of definition to capture the invariable aspect of the use of a word, that is, its semantic invariant. Definition also helps in clear understanding of concepts and in the development of thought (cf. Ogden \& Richards, 1946, pp. 14-15). It is the invariant semantic core that constitutes the sense of a word. In consonance with this understanding, Newmark (1984) identifies three series of semantic categories in which lexical items can be tested in order to establish their senses in the context; they are the ordinal series, the qualitative, and the logical series (pp. 117-120). By implication, lexical items in alternative structural realizations compete for the status of being the optimal output of a particular input. The most harmonic output - the one that best satisfies or minimally violates the full set of ranked constraints in a given language is the optimal one (cf. Reiter, 1993, p. 299; Legendre, 2001, p. 3). This assertion again reminds one of structuralism again, which is one of the most influential trends in the twenty first century linguistics. In reaction to the idea of the structuralist School, Goddard (1998) stipulates:

The sense of an expression is the totality of its possible relations with all other words. Semantic analysis therefore consists of systematically comparing and contrasting related words (known as a semantic field or domain) and summarizing the similarities and contrasts in the most economical way. (p. 43)

This is in accordance with Palmer's (2002) claim that sense relates to the complex system of relationship that holds between the linguistic elements themselves (p. 29). This implies that lexical items or words have domains of use. Then the words consist of components which are semantic primes. Such primes constitute the "indefinibilia" - they cannot be defined (Wierzbicka, 1996, pp. 9-10). In other words, the conceptual nucleus of a word, the sense can only be defined appropriately by the use of the semantic primes.

\section{Equivalence and Translation Practice}

In his (cf. Ifesieh, 2010, p. 113) explication of equivalence in relation to translation practice, he quotes Nida 
(1949), who suggests three principles which govern semantic analysis and classification (pp. 151-157). These principles are concerned with: (1) the non existence of real synonyms; (2) the definability of meaning by environment; and (3) the non-conformity between systems of symbolization. The non-existence of real synonyms simply implies that no two words are exactly alike, that is, absolute synonymy is ruled out. In line with this claim, Cruse (2000) explains that synonyms are words whose semantic similarities are more salient than their differences (pp. 156-160). The second point has been described in one of the previous paragraphs, but the third point must be emphasized since it has a very serious implication for translation. The non-conformity between systems of symbolization simply means that languages differ in the way in which they classify phenomena or in their ways of conceptualization and reconceptualization. This fact leads to lack of equivalence in translation, which is the greatest problem of translation theory. According to Hefzallah (1970), lack of equivalence means two things: (1) the meanings attached to corresponding words in two languages are not identical; and (2) lack of words in the language of rendition corresponding to words in the original language (p. 181). Confronted by the problem of lack of equivalent word in the TL, the translator may choose between a few alternatives: (1) transliteration; (2) adaptation of the new word according to the phonetic patterns of the language; and (3) the coining of new words. These alternatives may not be solutions to every problem of lack of equivalence. Therefore, the translator is free to choose what he/she deems fit in any given translation difficulty situation, just like an expert engaged in a human action. The decision taken is dependent on the skopos of the translation. For instance, when translating a word that stands for a concept unknown in the country of rendition, that is, the language of rendition does not have a corresponding concept; it is believed by some scholars that it is safer to leave the word untranslated. In other words, borrowing may be necessary to fill a semantic lacuna (Kolawole, 2003, p. 134). By implication, there is translatability problem, which can be either linguistic or cultural (House, 1973, pp. 166-167; Harris, 1991, p. 347; Bassnett, 1996, p. 32; Nida, 2004, p. 157). However, in this write up, emphasis has been on linguistic approach to translation. Sequel to that, the concern is on linguistic translatability problem, which is lack of lexical or syntactical substitute in the TL for an item in the SL. For example, the German statement- "Um wieviel Uhr darf man Sie Morgen anrufen?" is linguistically difficult to translate (into English) because it involves a structure that does not exist in English. Yet the statement can be adequately translated into English once the rules of English structure are applied: "What time would you like to be phoned tomorrow?" Argued along this line, one can propose that anything that can be said in one language can be said in another too, unless the form is an essential element of the message. Thus, Pedro (1999) states:

The translatability of a text is guaranteed by the existence of universal categories in syntax, semantics, and the (natural) logic of experience. Should a translation nevertheless fail to measure up to the original in terms of quality, the reason will (normally) be not an insufficiency of syntactic and lexical inventories in that particular TL, but rather the limited ability of the translator with regard to text analysis. (p. 552)

This assertion shifts the blame of errors in translatorial action to the translator. However, experience has shown that irrespective of the versatility and proficiency of translators in the two languages in contact, translation of cultural texts such as literary ones has always exhibited loss, addition, or skewing of information. The different editions and versions of the Holy Bible are typical examples. Nevertheless, it can be admitted that mistranslation may arise in cases where the translator's cognitive baggage and cognitive context are insufficient to extract sense and meaning from the SL text for onward transmission into the TL text (Salama-Carr, 1998, p. 113). For example, 
Mayanja (1999) indicates some mistranslations of Things Fall Apart (TFA) by two different translators, one from East Germany and the other from West Germany (pp. 185-206). The mistranslations occur on account of lack of cognitive elements and complementary information on the part of the translators: "Okika was a great man and an orator" (Achebe, 1958, p. 143).

(1) Translation: "Okika war ein grosser Mann und ein grosser Redner obendrein" (Anon, 1976, p. 204).

(2) Translation: "Okika war ein angesehener Mann und ein guter Redner obendrein" (Heusler \& Petzold 1983, p. 220).

The first translation is problematic on account of the use of the word "gross" which implies not only great, but also tall to qualify Mann, but the same adjective qualifies "Redner" better than "gut" in the second translation, bearing in mind the context of use. Therefore, the East German translation is partially ambiguous and inexact. The second semantic translation of the same sentence is more exact.

\section{Characteristics of Sense}

Arising from the preceding paragraphs, Ifesieh (2010) makes the following assumptions can be made as regards sense (p. 115):

(1) Sense indicates "what is said", the direct information;

(2) The sense of a word is the objective use of the word;

(3) The sense in a given linguistic discourse relates to the words and word groups;

(4) Sense is formal, and therefore a linguistic factor in translation;

(5) Sense signifies; it is the tacit knowledge of something in a socioculture;

(6) The sense of a given lexical item is relatively narrow and is independent on its environment for its truth-value, for example, if an aphasiac says, "give me a fork to drink syrup", it makes sense, but the meaning is unclear. A fork cannot be used to drink syrup, but a spoon. In the sentence above $a$ fork retains its sense even though it is semantically ill-applied in the correct syntactic structure;

(7) Sense and denotation are interdependent (Lyons, 1981, p. 152). For example, sense relation holds between cow, animal, and calves. Cow denotes a class of entities which is a proper subclass of the class of sub-entities denoted by animal. Therefore, sense denotes, but it does not connote;

(8) The sense of a word can be described as an entity.

\section{Semantic Translation as Sense Translating}

In furtherance of his argument, Ifesieh (2010, p. 115) refers to Newmark's definition of semantic translation which says: "semantic translation attempts to render, as closely as the semantic and syntactic structures of the second language allow, the exact contextual meaning of the original" (Newmark, 1971, p. 164; Newmark, 1984, p. 39). Sequel to this, semantic approach to translation can be defined as the act of replacing a text in a SL with an equivalent text in a TL. The sense expresses the thought in the text. However, the thought is limited to the lexical item(s) in question and its/their function/s in a given syntactic or linguistic discourse. Since the sense is a linguistic factor, the thought changes with alteration in the grammar or word function in the sentence structure. The sense of a word is not dependent on its use. If that were the situation, language would not be organized. However, every word has a conceptual nucleus and the different aspects of meanings outside this nucleus are 
dependent on the nucleus, sense. In translation, the sense concerns itself basically with the direct information which is only part of a full meaning. On account of dynamism and complexity of languages, the translator is expected to be well versed in both the target and source languages. He/she should be conversant with both the connotations and denotations of words. If a translator translates semantically, he/she replaces the direct information of the SL text in the TL text. Here are examples taken from Things Fall Apart (TFA):

(1) Igbo oral proverb: Ílú bụ mmanụ é ji èrí ókwu.

Semantic translation: Proverbs are palm oil with which words are eaten (Achebe, 1958, p. 5).

Communicative translation: The use of proverbs smoothens and gives a persuasive force to expressions.

(2) Igbo oral proverb: Ndị ichie ányị sị nà ánwú gà ámụsá ndị kwụ ọtọ túpú ọ mụsá ndị nọdụrụ àlà.

Semantic translation: Our elders say, that the sun will shine on those who stand before it shines on those who kneel under them (Achebe, 1958, p. 6).

Communicative translation: First come first served.

(3) Igbo oral proverb: Nwátà kwọo áká, ò sòró ndi ézē rié nri.

Semantic translation: If a child washed his hands he could eat with kings (Achebe, 1958, p. 6).

Communicative translation: A hard worker gets what he wants.

(4) Igbo oral proverb: Ọnwá tíwe íjè à gụwá ónyé ngwụrọ.

Semantic translation: When the moon is shining, the cripple becomes hungry for a walk (Achebe, 1958, p. 7).

Communicative translation: Everyone like pleasurable condition, even the cripple.

(5) Igbo oral proverb: Mgbè nwóké nà chi yá nà ndị ìchíe dị ná mma, òwùwè-íhē-úbì yá gà-àdị úkwú mọbụ dị ṃpe dịkà úgbó yá hà.

Semantic translation: When a man is at peace with his gods and ancestors, his harvest will be good or bad according to the strength of his farm (Achebe, 1958, p. 13).

Communicative translation: When one is naturally favoured, he will have either a bumper or a little harvest depending on the size of his farm.

(6) Igbo oral proverb: Há nà-ágáfē nmiri àsáá (na ágụ àsáá) ịkọ úgbó há.

Semantic translation: They cross seven rivers (and seven jungles) to make their farms (Achebe, 1958, p. 13).

Communicative translation: They surmount a great deal of hurdles to cultivate their farms.

(7) Igbo oral proverb: Égbé bèré ùgò bèré nké sị ìbè yá ébèlà, nkù kàá yá.

Semantic translation: Let the kite perch and let the eagle perch too. If one says no to the other let his wings break (Achebe, 1958, p. 14).

Communicative translation: Live and let live.

(8) Igbo oral proverb: Áwọ á nághị àgbá ọsọ éhíhìe nà nkịtị.

Semantic translation: A toad does not run in the day time for nothing (Achebe, pp. 15, 143).

Communicative translation: There is no smoke without fire.

(9) Igbo oral proverb: Ó wétéré ọji wètèrè ndụ.

Semantic translation: He who brings kola brings life (Achebe, 1958, p. 5).

Communicative translation: He who offers a present to his visitor wishes him well as well as welcome. 


\section{Discussion}

The semantic approach to translation is used by most African writers in rewriting the oral literature. A typical example of such an African writer is Chinua Achebe as seen above. He predominantly employs the approach in translating Igbo oral proverbs into English. In the examples above, it is noticeable that semantic translation is required to show the thought-process in the utterance. It also helps to retain the style and form of the original text in the target text. Invariably, the social context in which the SL text is produced is also recaptured via the approach. The ultimate effect of the approach is that it submerges the translator at an invisible realm while projecting the textual function of the source text at the target language end. In $T F A$, it can be noticed that Achebe appropriates the medium of English language to forge a prose universal in its reach which remains uniquely African and particularly Igbo in image, reference, and tonality. In Achebe's case, he has at his disposal the oral tradition but he also receives the European form, the novel via English language with which he re-enacts (cf. Askoy, 2001) the African tradition and peculiarities - ritual language, imagery, metaphor, the mythic vision, poetic resonance, idioms of powerful and ancient oral traditions, and most especially proverbs. With these resources, Achebe translates into the English target language a reinvigorated text which is new in form, subtle tool yet sturdy, flexible yet powerful enough to bear the weight and density of the sociocultural inheritance (Thelwell, 1996, p. 5). To Achebe, only a new English which is in full communion with its ancestral home, but altered to suit its new African environment can carry the weight of his African experience (Achebe, 2003, p. 65). Achebe achieves this through the application of the semantic approach to translation. The examples above show that the target texts exploit the syntactic possibilities of the SL in pursuit of sense relations in the texts. Nevertheless, communicative approach as seen above may be preferable to make the utterance on first reading more comprehensible and attractive. However, the discussion of communicative approach to translation, which attempts to produce on its readers an effect as close as possible to that obtained on the readers of the original is outside the scope of this article. Subsequently, sense in translation shows the direct information in the text. Such semantic translation that brings out the sense in the text is complicated, detailed, awkward, and concentrated. It appears to be much inclusive, while searching for one nuance of meaning or the other. Therefore, certain types of text should be translated semantically. For instance, scientific and legal texts ought to be translated semantically because scientific and legal languages differ from the ordinary language in the sense that its terms are clearly defined and its registers rigorously established.

The semantic approach to translation seeks alliance with the formal equivalence. Formal equivalence focuses attention on the textual function itself, in both form and content. Consequently, literary translators often adopt this approach, depending on the skopos of the translation. In such a translation, one is concerned with such correspondence as poetry to poetry, sentence to sentence, and concept to concept (Bassnett, 1991, p. 26). In literary translation, semantic configurations of the SL text are often a part of the message, because it calls the attention of the reader just like the content as in the case of the Igbo oral proverbs. When a literary work exploits the idiomatic capacities and special genius of the SL as in the literary texts, then the translator is under constraint to reflect such ingenuities in the TL text. The ingenuities are noticed not only in the literary, stylistic or genre model, but also in the ideologies, sociocultural prejudice and clichés of the original author (Albrecht, 1998, p. 262; Apel \& Koptzki, 2003, p. 6; Nida, 2004, p. 160). De Groot (1997) describes this type of translation as a 
horizontal translation, however, maintains that its counter part, vertical translation often co-occur with the former (p. 30). Contrary to the issues raised above, Toury (1995) supposes that it is the systemic position and the sociocultural-semiotic function which the SL text gives rise to that make the difference and not the surface realizations (p. 173). In his view, literary translation involves the imposition of conformity conditions beyond the linguistic and/or textual ones, namely to models and norms which are deemed literary at the target end. It thus yields a well formed text from the viewpoint of the literary requirements of the target language socioculture at various possible costs in terms of the reconstruction of features of the source text. This is a vertical view of translation which this paper does not totally subscribe to. One reason is that languages share universal principles and only vary in a few parameters in line with the various sociocultures; the parameters may of course give rise to use variations, which may not find any ready replacement in the TL socioculture (cf. Evans, 1998, p. 151). Secondly, literary translation serves as a vehicle for a cross-sociocultural enrichment and understanding (Venuti 1998, pp. 240-244; Apel \& Kopetzki, 2003, p. 59). Evan-Zohar (1997) also shares a similar view with Toury. However, his polysystem theory is not a watertight package, but rather a point of departure for further work (Shuttleworth, 1998, p. 179). The current trend in literary translation places emphasis on elaborating how the poetics of translation depends on and contributes to literary, linguistic, and cultural change (Gentzler, 1998, p. 170), thereby watering down the argument of Toury and Evan-Zohar.

Finally, semantic translation is different from both word-for-word and literal translations. In the word-for-word translation, the source language word order is preserved and the words are translated singly by their most common senses out of context. Bassnett (1996) calls this type of translation gloss translation. The main use of word-for-word translation is to understand the mechanics of the SL (Newmark, 1998, pp. 45-46). For example:

German: Um vieviel Uhr darf man Sie Morgen anrufen?

English: Around how many clock allows one you tomorrow to call?

In literal translation, the SL grammatical constructions are converted to their nearest TL equivalents, but the words are again translated singly, out of context. This also serves as a pre-translation process that indicates the problems to be solved. For example, using the same sentence above:

German: Um wieviel Uhr darf man Sie Morgen anrufen?

English: Around how many clock is one allowed to call you tomorrow?

The same German sentence translated semantically will read "what time would you like to be called tomorrow?" Semantic translation is therefore flexible and gives room for the translator's intuitive empathy with the original (cf. Ifesieh, 2010, pp. 119-120).

\section{Conclusion}

Literary translation as an aspect of applied linguistics is a linguistic exercise aimed at reproducing the message of the SL in the TL in such a way that the content and form of the original is retrained in the translation. This is usually achievable through semantic approach to translation as demonstrated in this paper. However, there is one other approach to translation, which is not handled in this article, which is communicative approach to translation, which aims at achieving a dynamic equivalence. Essentially, semantic approach submerges the translator, while at the same time projects the cadence, thought process, vigour and ingenuity of the original text in the TL text. 


\section{References}

Achebe, C. (1958). Things fall apart (p. 158). London: Heinemann.

Achebe, C. (2003). The African writer and the English language. In I. Okpewho (Ed.), Chinua Achebe's things fall apart: A case Book (pp. 55-65). Oxford: Oxford University Press.

Ajunwa, E. (1991). Translation theory and practice (pp. 104). Onitsha: University Publishing.

Albrecht, J. (1998). Literarische Übersetzung: Geschichte-Theorie-kulturelle Wirkung (Literary translation: History-theory-cultural effect) (pp. 255-269). Damstadt: Wissenschaftlische Buchgesellschaft.

Anon, E. G. (1976). Okonkwo oder Das Alte stürzt (Okonkwo or things fall apart) (p. 207). DDR Fassung.

Apel, F., \& Kopetzki, A. (2003). Literarische Übersetzung: 2. vollständig neu bearbeitete Auflage (Literary translation: Complete new, 2nd edition) (p. 148). Stuttgart: J. B. Mezler.

Askoy, B. (2001). Translation as rewriting. Translation Journal, 5(3), 14.

Bassnett, S. (1996). Translation studies (revised ed., p. 137). London: Rutledge.

Brown, K., \& Miller, J. (1992). Syntax: A linguistic introduction to sentence structure (2nd ed., p. 382). London: Routledge.

Catford, J. C. (1965). A linguistic theory of translation: An essay in applied linguistics (p. 101). London: Oxford University Press.

Clark, H. H., \& Clark, E. V. (1977). Psychology and language: An introduction to psycholinguistics (p. 608). New York: Harcourt Brace.

Cruse, D. A. (2000). Meaning in language: An introduction to semantics and pragmatics (p. 424). Oxford: Oxford University Press. Crystal, D. (2008). A dictionary of linguistics and phonetics (6th ed., p. 281). Oxford: Blackwell.

De Groot, A. M. B. (1997). The cognitive study of translation and interpretation. In J. H. Danks, G. M. Shreve, S. B. Fountain, and M. K. McBeath (Eds.), Cognitive process in translation and interpretion (pp. 25-56). London: SAGE Publications.

Eco, U., \& Nergaard, S. (1998). Semiotic approaches. In M. Baker (Ed.), Routledge encyclopedia of translation studies (pp. 218-222). London: Routledge.

Even-Zohar, I. (1997). Polysystem studies. Poetics Today: International Journal for Theory and Analysis of Literature and Communication, 11(1), 262.

Evans, R. (1998). Metaphor of translation. In M. Baker (Ed.), Routledge encyclopaedia of translation studies (pp. 149-153). London: Routledge.

Gentzler, E. (1998). Poetics of translation. In M. Baker (Ed.), Routledge encyclopaedia of translation studies (pp. 167-170). London: Routledge.

Goddard, C. (1998). Semantic analysis: A practical introduction (p. 411). Oxford: Oxford University Press.

Haegeman, L. (1993). Introduction to government and binding theory (p. 618). Oxford: Blackwell.

Hampsher-Monk, I. (1992). A history of modern political thought: Major political thinkers from Hobbes to Marx (p. 609). Malden, USA: Blackwell Publishing.

Harris, Z. (1991). A theory of language and information: A mathematical approach (p. 428). Oxford: Clarendon.

Hefzallah, I. M. (1970). The art of translation. Babel, xvi(4), 166-167.

Heusler, D., \& Petzold, E. (Trans.). (1983). Okonkwo oder Das Alte stürzt (Okonkwo or things fall apart) (p. 239). Frankfurt am Main: Suhrkamp.

House, J. (1973). On limits of translatability. Babel, XIX(4), 166-167.

Ifesieh, E. C. (2010). Sense in translation. Abraka Humanities Review, 3(1), 105-124.

Kempson, R. M. (1979). Semantic theory (p. 216). Cambridge: Cambridge University Press.

Kolawole, S. O. (2003). The relevance of borrowing in translation. WAJOLT, 1, 133-140.

Koller, W. (1983). Einführung in die Übersetzungswissenschaft (p. 291). Heidelberg: Quelle and Meyer.

Lambert, J. (1998). Literary translation research issues. In M. Baker (Ed.), Routledge ecyclopedia of translation studies (pp. 130-133). London: Routledge.

Legendre, G. (2001). An introduction to optimality theory in syntax. In G. Legendre, J. Grimshaw, and S. Vikner (Eds.), Optimality - theoretic syntax (pp. 1-27). London: the MIT Press.

Lyons, J. (1981). Language and linguistics: An introduction (p. 356). Cambridge: Cambridge University Press.

Malmkjaer, K. (2002). The linguistic encyclopaedia (2nd ed., p. 643). London: Routledge.

Mayanja, S. (1999). Untersuchungen zum Problem der Übersetzung afrikanischer Literature in Deutsch (Investigations on the problems of translating African literature into German) (pp. 78-83). Hannover: Rennovar Verlag.

Mey, J. L. (2001). Pragmatics (2nd ed., p. 392). Malden, USA: Blackwell Publishing. 
Ndimele, O. M. (1999). A first course on morphology and syntax (p. 222). Port Harcourt: Emhai Printing and Publishing Co..

Ndimele, O. M. (2004). The parametres of universal grammar: A government-binding approach (p. 118). Owerri, Nigeria: African Educational Services.

Newmark, P. (1971). Communicative and semantic translation. Babel, xxi(4), 163-177.

Newmark, P. (1984). Approaches to translation (p. 200). Oxford: Pergamon press.

Newmark, P. (1998). A textbook of translation (p. 292). Hemel Hempstead: Prentice Hall Europe.

Nida, E. A. (1949). Morphology: The descriptive analysis of words (2nd ed., p. 342). Canada: The University of Michigan Press.

Nida, E. A. (1959). Principles of translation as exemplified by Bible translating. In R. A. Brower (Ed.), On translation (pp. 11-31). Cambridge: Harvard University Press.

Nida, E. A. (2004). Principles of correspondence. In L. Venuti (Ed.), The translation studies reader (pp. 153-167). New York: Routledge.

Ogden, C.K., \& Richards, I. A. (1946). The meaning of meaning (8th ed., p. 363). New York: Harcourt Brace and World.

Okri, B. (1996). The famished road (p. 500). Ibadan: Spectrum Books.

Palmer, F. R. (2002). Semantics (2nd ed., p. 221). Cambridge: Cambridge University Press.

Pedro, de R. (1999). Cultural untranslatability. META, XLIV(4), 546-559.

Radford, A. (1989). Transformational grammar (p. 605). Cambridge: Press Syndicate of University of Cambridge.

Reiss, K. (2004). Type, kind and individuality of text: Decision making in translation. In L. Venuti (Ed.), The translation studies reader (pp. 168-174). New York: Routledge.

Reiter, E. (1993). Lexical choice and lexical preferences. In H. Horacek and M. Zock (Eds.), New concepts in natural language generation: Planning, realization and systems (pp. 297-301). London: Pinter Publishers.

Ruwet, N. (1973). An introduction to generative grammar (p. 372). London: North-Holland Publishing Company.

Salamar-Carr, M. (1998). Interpretive approach. In M. Baker (Ed.), Routledge encyclopaedia of translation studies (pp. 112-114). London: Routledge.

Schäffner, C. (1998a). Action (theory of "translatorial action”). In M. Baker (Ed.), Encyclopedia of translation studies (pp. 3-5). London: Routledge.

Schäffner, C. (1998b). Skopos theory. In Moner Baker (Ed.), Encyclopedia of translation studies (pp. 235-238). London: Routledge.

Seuren, P. A. M. (1985). Discourse semantics (p. 544). Oxford: Basil Blackwell.

Shuttleworth, M. (1998). Polysystem theory. In M. Baker (Ed.), Routledge encyclopaedia of translation studies (pp. 176-179). London: Routledge.

Thelwell, M. (1996). Telling the truth is the only way. In E. Ihekweazu (Ed.), Eagle on Iroko: Selected papers from the Chinua Achebe international symposium 1990 (pp. 2-21). Ibadan: Heinemann.

Toury, G. (1995). Descriptive translation studies and beyond (p. 319). Amsterdam: John Benjamins Publishing.

Venuti, L. (1998). Strategies of translation. In M. Baker (Ed.), Routledge encyclopaedia of translation studies (pp. 240-244). London: Routledge.

Vermeer, H. J. (1998). Didactics of translation. In M. Baker (Ed.), Encyclopedia of translation studies (pp. 60-63). London: Routledge.

Wierzbicka, A. (1996). Semantics: Primes and universals (p. 500). Oxford University Press. 